\title{
The use of multimodal tips in lexical inferencing of English as a foreign language
}

\author{
Patricia Nora de Souza Ribeiro \\ Universidade Federal de Juiz de Fora \\ patnora.souza@gmail.com \\ Renata Bittencourt Procópio \\ Universidade Federal de Juiz de Fora \\ procopiorenata@yahoo.com.br \\ Rachel Terrigno Cunha Reis \\ Universidade Federal de Juiz de Fora \\ rachel tac@hotmail.com
}

\begin{abstract}
The present work is an exploratory study aimed at investigating the use of multimodal tips in the lexical inferencing of English as a foreign language. On theoretical grounds, the work is based on the assumptions of Connectionism Approach and Lexical Inferencing. In the experiment,162 students of English at the elementary level, were divided into two groups: experimental and control group. In the experimental group, Group A received oral and written tips, group B received only oral tips, and group $\mathrm{C}$ only written tips to infer the meaning of the target vocabulary. In the control group, group D did not receive any tips. In the analysis, data generated in the vocabulary test and evaluation questionnaire were considered. The results show that the use of both modalities of tips, oral or written, may contribute to inferencing and vocabulary learning. However, the combined use of oral and written tips revealed to be more efficient. Besides, in the comparative condition, the relevance of oral tips, in an explicit approach, for inferencing and vocabulary learning was observed. With this research, we intend to contribute to the students' development of lexical inferencing and memory retention of the vocabulary in English as a Foreign Language.
\end{abstract}

Keywords: English; lexical inferencing; reading. 


\section{Resumo}

O presente trabalho investiga o uso de dicas multimodais para inferência lexical em inglês como língua estrangeira. Este trabalho fundamenta-se nos pressupostos da Abordagem Conexionista e Inferência Lexical. No âmbito da metodologia, o experimento foi aplicado a 162 participantes em nível elementar de inglês, divididos em grupo experimental e controle. O grupo A recebeu dicas orais e escritas, o grupo B recebeu dicas orais e o grupo $\mathrm{C}$ apenas dicas escritas para inferir o significado das palavras testadas. $O$ grupo controle, grupo $\mathrm{D}$, não recebeu dica. Essa distinção foi feita para investigar os impactos das dicas multimodais no processo de inferência lexical. Para a análise, consideram-se os resultados obtidos nos testes de vocabulário e questionário. Os resultados indicam que ambas as modalidades de dicas, oral ou escrita, podem contribuir para inferência e aprendizado de vocabulário. Entretanto, o uso combinado de dicas orais + escritas foram mais eficientes no aprendizado. Além disso, na condição comparativa, observou-se a relevância das dicas orais, em uma abordagem explícita, para o aprendizado. Com esta pesquisa, busca-se contribuir para o desenvolvimento no aluno da estratégia inferência lexical e a retenção na memória do vocabulário em inglês como Língua Estrangeira.

Palavras-chave: Língua inglesa; inferência lexical; leitura.

\section{Introduction}

Recent studies have investigated and pointed out the relevance of hypermedia to vocabulary learning in a foreign language (SADEGHI; AHMADI, 2012; PROCÓPIO, 2016, AZEVEDO, 2017). In this context, the present study aims at investigating the role of oral and written tips for lexical inferencing and memory retention of the target vocabulary in webcomics. In detail, what is proposed is the use of tips to help students explore the multimodality present in the webcomics. Those tips would guide them, highlighting in links what is relevant to the inferencing of the target vocabulary and the understanding of the story.

The motivation for using tips emerged from the literature that points out the relevance of hypermedia for vocabulary learning and also from the implicit vocabulary teaching approach of English for Specific Purpose which has emphasized lexical inferencing activities (SOUZA; BASTOS, 2001; RAMOS, 2015). Most of these activities demand from the students the production of only one meaning for the target word in the text, without any guidance or tip that could help them, that is, the activities do 
not have the objective to teach lexical inferencing strategies but just ask students to look at the text and give the meaming of words without any help. questions:

Thus, within this context, we aim to answer the following research

(1) Does the use of tips help lexical inferencing in English as a Foreign Language?

(2) What are the impacts of using oral and written tips for inferencing and retention, in the short term, of English vocabulary as a foreign language in the experimental group (A, B, and C)?

(3) Comparatively, which of the two modalities, oral and written, are more efficient for inferencing and retention, in the short term, of English vocabulary?

For this research, we selected the webcomics as a productive environment for vocabulary learning since it incorporates media resources into traditional comic books. Furthermore, webcomics are worldwide known and very popular, especially with the younger audience (SANTOS; GANZAROLLI, 2011, p. 6).

To accomplish the proposed objectives, sections 2 and 3 discuss the assumptions of Connectionism Approach and researches on Lexical inferencing, focusing on vocabulary learning in a hypermedia environment. The following sections, sections 4 and 5, present the methodology and the analysis of the data, respectively, and the last section, section 6 , the conclusion.

\section{Lexical inferencing}

Researchers on foreign language reading education recognize the importance of a threshold level of lexical competence to understand a text (SCARAMUCCI, 1995, p. 37; HOSTETLER, 2013, p. 5-6). They point out, therefore, a strong relationship between lexical competence and reading comprehension. Scaramucci (1995, p. 83), in her Rich Lexical Knowledge Model, advocates a threshold level of vocabulary knowledge which comprises both a quantitative dimension with emphasis on a minimum number of words necessary for comprehension, as well as a qualitative dimension which points out the various levels of this 
knowledge: semantic, lexical, syntactic, phonological, morphological and pragmatic-discursive.

In this context, researchers consider the need for an integrated approach which comprises both implicit vocabulary learning and teaching, which happens in context and contributes to lifelong learning by means of lexical inferencing, as well as explicit teaching which speeds learning enabling the construction of a lexical base through strategies and exercises that control vocabulary exposure and repetition.

However, critically reviewing the literature on foreign language teaching, particularly vocabulary teaching in the reading context, a tendency that privileges implicit vocabulary teaching, through inferencing in context is observed.

According to Chegeni \& Tabatabaei (2014, p. 306) and Hostetler (2013, p. 63), lexical inferencing is a reading strategy in which the reader uses all linguistic, contextual knowledge and non-linguistic clues to guess the meaning of the unknown vocabulary. In this way, in the process of inferencing, the reader makes a hypothesis of the meaning of the unknown vocabulary, based on various sources of knowledge, both linguistic and extralinguistic.

Although there are advances in vocabulary studies, in the context of teaching reading, there are orthodox vocabulary exercises that only highlight words in the text in which the students have to infer, define or translate its meaning without help or instruction. Thus, more research is needed in the field of lexical inferencing to provide teachers with more theoretical sources and practical examples of exercises that provide effective learning.

\section{The connectionism approach}

The Connectionism Approach, one of the approaches of Cognitive Linguistics, aims at explaining how storage, processing, and recovery of knowledge work.

This approach is grounded on the Neuroscience foundations and on the technological advances in computing to explain the brain's function and information processing which involves the auditory, motor, visual and articulatory systems from the cellular level (synapses between neurons) to the social level (communication and learning). 
To the connectionism, the mind is compared to a computer, an operational system, which processes the information that enters through the senses, for example, vision and hearing (input data) and generates a product (output), the learning.

Concerning language acquisition, the Connectionism Approach understands this process like any other human cognitive capacity, which results from the interaction of many primordial cognitive systems such as perception, memory, concept formation and problem-solving (MOTA; ZIMMER, 2005, p. 156).

Cognitive processing is directly linked to the way the neurons are organized and linked in the brain. Thus, learning takes place through neural synapses that promote communication among the neurons by electrical impulses transmission in a simultaneous and parallel way throughout the brain. In this way, one of the principles of the connectionism approach concerns the subtle changes that occur in the neural networks through these synapses. It explains the fact that we have to establish new neural connections to acquire new knowledge, such as a Foreign Language, as the more frequent or recurrent the information more the neural networks are reinforced or activated.

In other words, by stimulating neural connections, some neural electrical activity patterns become stronger, more intensely marked in the neural networks, thus creating a basis for memory formation and learning. The learning of both mother tongue and FL happen by reinforcing specific electrical patterns among the neurons, activated by the creation of new memories and recovering pre-existing ones, since the brain works through the association of the information that circulates in neural networks. Thus, the richer the networks of associative relations, the more chances of learning. Therefore, the connectionist paradigm emphasizes the importance of the frequency of input exposure in the teaching and learning process (ZIMMER, 2010, p. 118).

The Cognitive Theory of the Multimedia Learning by Mayer (2001, p. 44) also points out the relevance of neural connections reinforcement since, according to this model, learning becomes more significant by the exposure to multimodal information: visual information selected by the eyes and verbal information graphically represented or by sound record, selected by both the ears and the eyes. In other words, these multiple and varied forms of information, when integrated, enable great and more 
meaningful contact with the input producing a salience effect that activates and reinforces the neural networks.

In the following section, we describe the methodology of the present research taking up the objectives and the research questions that guide the present study. Next, we present the data analysis and the conclusion of the study.

\section{Research methodology}

The present study used tests (pre-test and post-test) and questionnaries (questionnaire of identification and evaluation) to collect data. It has several stages, which together allowed us to investigate the use of tips in lexical inferencing described in the following.

\subsection{Webcomics with written tips}

The webcomics chosen for the experiment was called The Reconstruction. It is about the investigation of a mystery: Monica's toys disappearance. For this reason, the story has sub-stories that tell the different perspectives of this fact in the vision of the characters: Monica, Maggy, Jimmy Five, and Smudge. To solve this mystery and also prove he was not guilty, Jimmy Five is in charge of investigating the case. For this research, we used only Monica's and Smudge's version of the story.

To prepare the environment to be tested, the program Adobe Reader was used since it is easy and straightforward to access. With the resources of this program, it was possible to highlight the target words in yellow and create links for each of them containing written tips.

The tips provided guidelines for the exploration of the multimodality present in the webcomics. They led students to observe more closely what was happening in each scene. These tips were in Portuguese, but the target words in English to provide more exposure to them.

Eleven keywords (began, bush, fix, guilty, hiding, messed up, oven, plans, showed up, take care and yell) selected from the investigated webcomics that might be unknown for elementary students were marked in yellow in the balloons, and there were tips in links attached to them. The tips were made with the sticky note tool of the Adobe Reader. By clicking on the highlighted words, students could access the written tips that 
referred to the multimodal elements of the scene, such as the position of the characters, their gestures, and their facial expressions. Most of the tips were in two different forms: filling in the gaps or multiple-choice that offered options for the inferenc of the highlighted vocabulary.

\subsection{Research tools and procedures}

The corpus of the present exploratory study has 162 high-school students between 12 and 16 years old, from the Application College of a Federal University of Minas Gerais. The students invited to participate in the research were in the 8th and 9th grade.

The participants were divided into four groups (Experimental Groups: A, B, and C; Control group: D). In the experimental group, group A received oral and written tips, group $B$ received oral tips, and group $C$ received written tips. In the control group, group D did not receive any tips. The students were separated into groups to investigate the impacts that the tips have on the process of students' lexical inferencing.

Group A received oral tips provided by the researcher, in an introductory class, according to an explicit teaching approach. In this class, the researcher presented the characters of the story and the target words. Following, this group read the webcomics containing written tips on links for the target words, highlighted in yellow, according to an implicit learning approach, which means that the researcher did not do any intervention or give any help to the students. Group B received only the oral tips in the introductory class, and read the webcomics without any tip or help by the researcher. Group $C$ received only written tips on links in the webcomics and explored the tips also without the help of the researcher. Group D did not receive any tips.

On the first day of the intervention, which took place in the classroom, parental and student's terms of free and clarified consent were collected. It is important to mention that this study was approved by the UFJF Human Research Ethics Committee, under CAAE 86638418.6.0000.5147. The students also filled in the identification questionnaire and did the placement test.

The questionnaire of identification (see Appendix A) was applied at the beginning of the research with 12 questions in total to identify the participants. 
Considering the answers obtained in the questionnaire, 96.9 percentage points (\%) of the students said they had already read Monica's gang comic books, but only $31.0 \%$ had read webcomics. Although the students were familiar with comic books, only $43.2 \%$ said they had read this textual genre. Still considering the profile of students, $34.7 \%$ said they studied English in a private course, and $55.4 \%$ believed they were at the elementary level of English, $40.8 \%$ at the intermediate level and $3.6 \%$ at the advanced level. However, in the research, the students were given an international placement test: the Solutions Placement Test, to confirm their proficiency level.

The Solutions Placement Test consists of three sections: First section: 50 multiple-choice questions in order to determine students' knowledge of grammatical and vocabulary points from elementary to intermediate levels. Second section: a text with 10 interpretive questions. Third section: a written production proposal. As in the placement test the proposal of written production is optional, we chose not to use it because it is an experiment in the context of teaching reading. The results of this test classified them at the elementary level of proficiency in English. This result was also confirmed by the student's proficiency level at the Application School (elementary level).

The test used to estimate the students' lexical knowledge was proposed by Scaramucci (1995), based on Dale's (1965) and on Richard's (1976) rich concept of vocabulary Knowledge before the experiment (pretest) and after the reading of the webcomics (post-test). The test had the list of the eleven keywords from the webcomics (began, bush, fix, guilty, hiding, messed up, oven, plans, showed up, take care, and yell) presented in a decontextualized way to avoid inferencing in context. The test has the following checklist of familiarity with vocabulary:

Table 1. Pre-test and post-test used in the experiment.

\begin{tabular}{|l|}
\hline A - I don't remember having seen this word before; \\
\hline B - I have seen this word, but I don't remember its meaning; \\
\hline C - I have already seen this word; \\
\hline D - I know this word. \\
\hline
\end{tabular}

Source: The authors

In the vocabulary post-test, applied after the reading activity, options $\mathrm{A}$ and $\mathrm{B}$ were considered together, indicating a lack of knowledge 
of the target words while options $\mathrm{C}$ and D indicated knowledge of the target words. The word learning percentage was calculated by the difference between the average number of students who know the words before and after the exposure to the webcomics.

On the second day, groups A and B (Experimental Groups) did the pre-test, and they also had an introductory class to introduce the webcomics. For this class, a power-point presentation was prepared to present the names of the characters of Monica's gang in English, and some pages of the story without the speech balloons. This presentation aims at exploring the visual aspect of the webcomics through oral tips, emphasizing essential details in the scenes that would help students to interpret them. The objective of this class was to present the eleven target words.

Diferently from the experimental groups, on the second day, groups C and D didn't have the introductory class. They read the webcomics on the tablets and the teacher explained to the students how to proceed during the reading activity. However, there was no interference regarding the content of the webcomics. Following, the students did the post-test and filled in the evaluative questionnaire.

At the end of the research right after the post-test, the students answered the questionnaire of evaluation (see Appendix B) which consists of 12 questions in total to give their opinion on the use of the hypermedia environment available by tablets to learn vocabulary.

\section{Data analysis}

This section of the study analyzes and discusses the results obtained with the application of the research tools both with the control group (group D) and the experimental group (groups A, B, and C) during all phases of the experiment.

\subsection{Comparative analysis of the results of the experimental group with the control group}

To answer the first research question:

(1) Does the use of tips help lexical inferencing in English as a Foreign Language? 
The results obtained, in general, offer evidence of the relevance of the tips for lexical inferencing. In other words, the participants' exposure to the oral or/and written tips contributed significantly to the inferencing and retention of the unknown vocabulary, as shown in graphic 1.

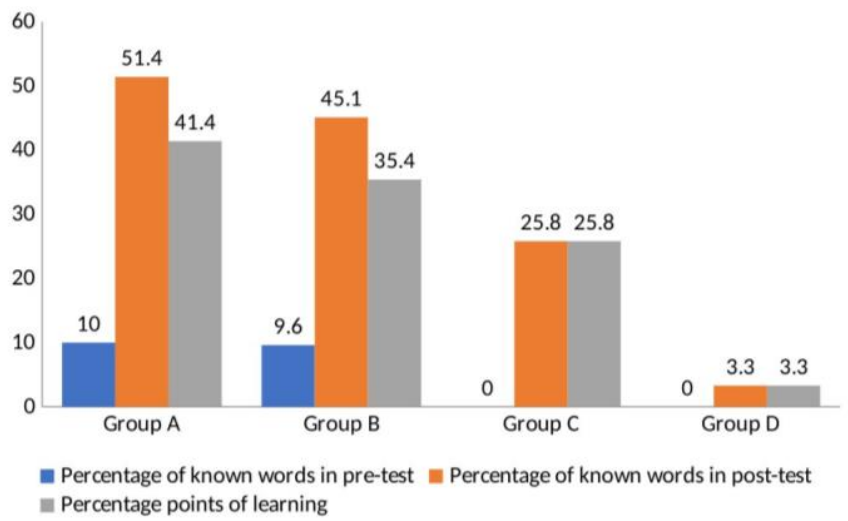

Graphic 1. Percentage points of learning in groups A, B, C e D. Source: The authors

The results of the post-test, applied immediately after the reading activity, show that the participants who had access to the tips, groups A, B, and $\mathrm{C}$, in oral and/or written modality, showed significant learning gain. It means that the use of tips promoted the correct inferencing of the meaning of the target words and the learning of the unknown words. Comparatively, the results between the pre-test and the post-test reveal an increase in knowledge of the words in the groups that had access to the tips: group A from 10.0 percentage points $(\%)$ to $51.4 \%$, group B from $9.6 \%$ to $45.1 \%$ and group $\mathrm{C}$ from $0 \%$ to $25.8 \%$. Group $\mathrm{D}$, which did not receive any tips, presented a discrete increase in knowledge of the tested words, from $0 \%$ to $3.3 \%$, much below the other groups. These results show the relevance of the tips for lexical inferencing and vocabulary learning.

Based on Mayer's Cognitive Theory of Multimedia Learning (2001), this result is due to the positive effect of double-coding, that is, the use of two or more ways of presenting information enables the learner to build richer mental representations, as well as to establish connections between them, facilitating learning. Likewise, Connectionist Theory points out that knowledge construction through multiple and varied types of 
information makes students receive positive stimuli that demand the involvement of the auditory, motor, visual and articulatory systems, which facilitates, therefore, the establishment of neuronal connections and, consequently, learning.

In the control group, although group D learned some keywords (the nouns: plan, $16.6 \%$, and oven $3.3 \%$ and the verbs: take care and began $3.3 \%$ ), this group showed a low performance with an average learning gain of only $3.3 \%$. Based on the analysis of the evaluative questionnaire, this learning gain is due to the students' knowledge of the world about Monica's gang. By answering question 11 (Did the choice of Monica's gang, with nationally well-known characters, influence the comprehension of the story?) $90.3 \%$ of the students reported that the choice of Monica's webcomics helped comprehension.

Besides, the multimodality present in the webcomics, especially the images that are part of the narrative, may also have helped. The images, colors, shapes, and symbols of the pictures are visual codes and, therefore, play a crucial role in the interpretative process. According to Mayer (2001) and Zimmer (2010) the presentation of information through more than one modality enables the representation of the linguistic input in the various media, providing contextualized salience and repetition, which is fundamental for learning.

Another factor that may have influenced the learning of group D is the use of hypermedia. By analyzing the data of the evaluative questionnaire, for question 3 (Do you think that reading webcomics are more efficient for learning than reading a comic book?) we observed that $64.5 \%$ of the students prefer webcomics. Still, for question 2 (How was your experience with the reading activity through the use of tablets?) $77.4 \%$ of the students said that the activity contributed to the learning of unknown words. From a Connectionist perspective, which emphasizes the importance of motivation and attention in learning, such a result points out the relevance of the inclusion of teaching resources that go beyond a traditional classroom.

\subsection{Experimental group's partial results}

In the following sections, we aimed at analyzing, in particular, the results of groups $\mathrm{A}, \mathrm{B}$, and $\mathrm{C}$ in vocabulary tests, considering the most and the least learned words, and the evaluative questionnaire to discuss the 
impacts of using multimodal tips. Based on the data, we aimed at answering the following research question:

(2) What are the impacts of using oral and written tips for inferencing and retention, in the short term, of English vocabulary as a foreign language in the experimental group (A, B and C)?

\subsubsection{Group A}

Group A is composed of 71 students of a high-school who had access to both oral tips provided in the introductory class and written tips, provided on links in the webcomics.

In the introductory class, the aim of presenting the webcomics without the speech balloons was not only eliciting from the students the target words but also teaching the ones they did not know, following an explicit teaching approach. The researcher directed students' attention to visual elements, such as the characters' movements; the sequence of the story and the elements of the scene.

Afterward, students went to the computer room where they accessed the webcomics with the speech balloons by using the tablets. They were allowed to consult all tips available on links during the reading activity. The webcomics group A had received the written tips available on links. The links allowed interactivity and dynamicity in reading.

The target words highlighted in yellow create salience and call the readers' attention, as well as re-present the vocabulary given in the introductory class reinforcing repetition and frequency in the memory, as postulated by Connectionism. It is worth to mention that the written tips were the same provided orally.

After the reading activity, the students answered the vocabulary post-test. The results of Group A show that the combination of oral and written tips provided a high learning rate of $41.4 \%$, as shown in table 2 . 
Table 2. Data from pre-test and post-test of Group A.

\begin{tabular}{|l|c|c|c|}
\hline Target Words & $\begin{array}{c}\text { Knowledge of } \\
\text { the words in the } \\
\text { Pre-test }\end{array}$ & $\begin{array}{c}\text { Knowledge of the } \\
\text { words in the Post- } \\
\text { test }\end{array}$ & $\begin{array}{c}\text { Learning in } \\
\text { percentage points }\end{array}$ \\
\hline Began & 11 & 34 & $32,3 \%$ \\
\hline Bush & 3 & 41 & $54,2 \%$ \\
\hline Fix & 15 & 56 & $58,5 \%$ \\
\hline Guilty & 7 & 36 & $41,4 \%$ \\
\hline Hiding & 10 & 21 & $15,7 \%$ \\
\hline Messed up & 1 & 6 & $7,1 \%$ \\
\hline Oven & 2 & 50 & $68,5 \%$ \\
\hline Plans & 21 & 55 & $48,5 \%$ \\
\hline Showed up & 4 & 28 & $34,2 \%$ \\
\hline Take care & 9 & 40 & $43,6 \%$ \\
\hline Yell & 1 & 32 & $44,2 \%$ \\
\hline Average Learning Gain & & $\mathbf{4 1 , 4 \%}$ \\
\hline
\end{tabular}

Source: The authors

The most learned words in group A were: oven, $68.5 \%$, and fix $58.5 \%$. The high learning rate of these words is because they belong to the verb and noun classes, which are more easily to learn than adjectives like messed up with a low learning rate of $7.1 \%$.

Based on the Connectionism Approach, it is emphasized that the words oven and fix are keywords and, therefore, appear five and six times, respectively, throughout the webcomics and in the tips provided to generate reinforcement. The learner's frequent exposure to lexical items interferes with the neural synapses responsible for learning, increasing the likelihood of a lexical item to be noted and, thus, learned.

Moreover, according to the Cognitive Theory of the Multimedia Learning by Mayer (1997; 2001), we believe in the positive effect of double-coding, in other words, the use of two or more modes of presentation of the information, which enables the learner to build richer mental representations as well as establish connections among them, facilitating learning. Based on these assumptions, we conclude that, although students had oral and written tips in different moments of the experiment, both tips may have contributed to inferencing and retention of the most learned words: oven and fix. 


\subsubsection{Group B}

The data of group B consist of 30 students of a high-school who had access to oral tips provided in the introductory class.

The first day of interaction between the researcher and group B followed the same steps of group A: Group B attended the introductory class in which the researcher provided the students with the oral tips. Unlike group A, on the second day, the participants of group B read the webcomics without the written tips on links for the target words.

Although group B didn't have access to written tips, the pre-test and post-test data showed an expressive average learning gain of $35.4 \%$. The gain of this group, smaller than that of group A, indicates that a high number of words became known after the reading activity. This result can be due to the oral tips the researcher provided while trying to elicit from the students the words tested. The words were listed on the board and repeated by them.

Based on the Connectionism Approach, the performance of group $\mathrm{B}$, exposed to the oral tips, was lower than that of group A because it did not have as much exposition to the lexical items as group A, which was exposed to oral tips and later to written tips. According to this Approach frequency is fundamental for learning.

In group $\mathrm{B}$, the most learned words were the verbs fix and showed up $(51.6 \%)$, yell $(45.1 \%)$, the nouns plans $(51.6 \%)$, and bush and oven $(45.1 \%)$, as shown in table 3 . 
Table 3. Data from pre-test and post-test of Group B.

\begin{tabular}{|l|c|c|c|}
\hline Target Words & $\begin{array}{c}\text { Students who } \\
\text { knew the words in } \\
\text { the pre-test }\end{array}$ & $\begin{array}{c}\text { Students who } \\
\text { knew the words in } \\
\text { the post-test }\end{array}$ & $\begin{array}{c}\text { Learning in } \\
\text { percentage points }\end{array}$ \\
\hline Began & 7 & 14 & $22,5 \%$ \\
\hline Bush & 2 & 16 & $45,1 \%$ \\
\hline Fix & 6 & 22 & $51,6 \%$ \\
\hline Guilty & 3 & 12 & $29 \%$ \\
\hline Hiding & 4 & 8 & $12,9 \%$ \\
\hline Messed up & 2 & 2 & 0 \\
\hline Oven & 4 & 18 & $45,1 \%$ \\
\hline Plans & 7 & 23 & $51,6 \%$ \\
\hline Showed up & 0 & 16 & $51,6 \%$ \\
\hline Take care & 3 & 12 & $29 \%$ \\
\hline Yell & 0 & 14 & $\mathbf{3 5 , 4 \%}$ \\
\hline Average Learning Gain & & \\
\hline
\end{tabular}

Source: The authors

We believe that this significant result is due to the different visual input offered: text, color, and pictures that illustrated the words tested. The researcher intensely explored it to help the student to correctly infer the meaning of the target words and retain them in the memory. According to Sadeghi and Ahmadi (2012) hypermedia favors the creation of varied contexts, rich in information, providing more resources for the search and evaluation of the meaning of the unknown word and, consequently, contributes to the realization of correct inferences.

\subsubsection{Group C}

To test the impact of the oral and written tips on inferencing, we also analyzed the data of group $\mathrm{C}$ that has 31 students of a high-school who had access to the written tips on links. This group did not have the introductory class, which provided oral tips.

The average learning gain of group $\mathrm{C}$ was $25.8 \%$, although smaller than that of groups $\mathrm{A}$ and $\mathrm{B}$, is a significant result showing the relevance of the written tips in inferencing.

The written tips, mainly in Portuguese, may have favored the learning of that group (group C). In the evaluative questionnaire, $86.6 \%$ of 
the students said they would understand the tips better if they were entirely in Portuguese (question 10: If the tip were only in Portuguese without any word in English, would you understand the tips better in links?)

Among the most learned words in group $\mathrm{C}$ are the noun plans $(51.6 \%)$ and the verb fix $(38.7 \%)$ while the least learned words are hiding and messed up (6.4\%), as table 4 shows.

Table 4. Data from pre-test and post-test of Group C.

\begin{tabular}{|l|c|c|c|}
\hline Target Words & $\begin{array}{c}\text { Students who knew } \\
\text { the words in the } \\
\text { pre-test }\end{array}$ & $\begin{array}{c}\text { Students who knew } \\
\text { the words in the } \\
\text { post-test }\end{array}$ & $\begin{array}{c}\text { Learning in } \\
\text { percentage } \\
\text { points }\end{array}$ \\
\hline Began & 0 & 6 & $19,3 \%$ \\
\hline Bush & 0 & 6 & $19,3 \%$ \\
\hline Fix & 1 & 13 & $38,7 \%$ \\
\hline Guilty & 1 & 8 & $22,5 \%$ \\
\hline Hiding & 2 & 4 & $6,4 \%$ \\
\hline Messed up & 0 & 2 & $6,4 \%$ \\
\hline Oven & 0 & 10 & $32,2 \%$ \\
\hline Plans & 7 & 23 & $51,6 \%$ \\
\hline Showed up & 0 & 11 & $25,8 \%$ \\
\hline Take care & 1 & 5 & $32,2 \%$ \\
\hline Yell & 0 & & $16,1 \%$ \\
\hline Average Learning Gain & & & $25,8 \%$ \\
\hline
\end{tabular}

Source: The authors

We observe that the verb fix, although it is a false friend of the word fixar in Portuguese, had a significant average learning gain. This word is a keyword and, therefore, appears six times throughout the stories. Such a frequency, according to the Connectionism Approach, reinforces the neural synapses responsible for learning, generating retention of the learned vocabulary. Furthermore, the multimodality present in the webcomics and the fact that Monica's webcomics are well-known by the group facilitated text comprehension.

\subsection{Comparative analysis of the experimental group (groups A, B, C)}

In this section, we aim at discussing comparatively the results obtained in the experimental group to answer the third research question: 
(3) Comparatively, which of the two modalities, oral and written, are more efficient for inferencing and retention, in the short term, of the vocabulary in English as a foreign language?

The analysis of the data in groups $\mathrm{A}, \mathrm{B}$, and $\mathrm{C}$ of the experimental group reveals that the use of tips in a hypermedia environment (webcomics) generated good results for inferencing and retention, in the short term, of the target words, considering mainly the results of the vocabulary tests, as graphic 2 reveals.

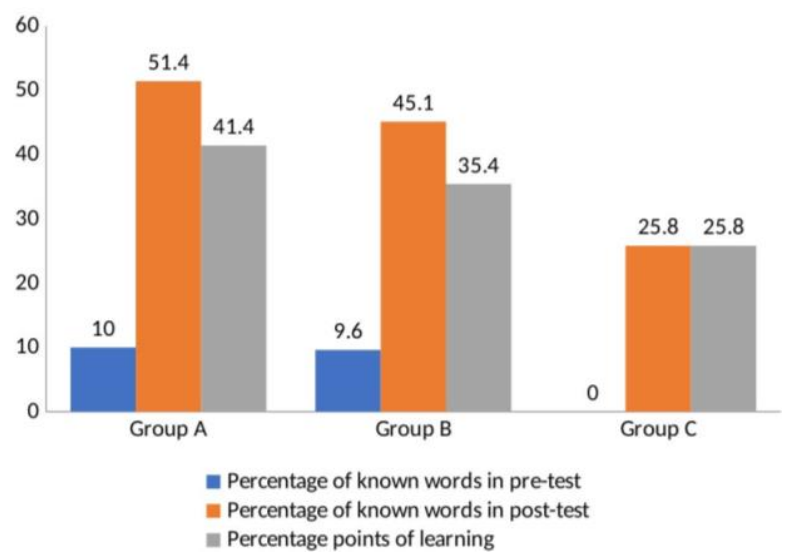

Graphic 2. Percentage points of learning of groups A, B, C. Source: The authors

Comparatively, we observe that oral + written tips, provided to group A, were the ones that most contributed to inferencing and retention of the vocabulary in the memory. It means that this group had more tips to associate and infer the meaning of the unknown items as well as had more exposure to the target words. It is due to the use of various media that benefits learning by allowing the student to build associations between the information provided, thus facilitating, according to Connectionism, the establishment of neuronal connections.

The oral tips provided to group B also deserve emphasis. They contributed to the inferencing and retention of the vocabulary in the memory. We believe that the interaction between the students and the researcher was one of the essential elements for the retention of the vocabulary taught. Events involving emotion trigger a more chemically 
stimulated and active brain. For this reason, events which have a higher emotional load are processed with more priorities and retained longer in memory (BOWER, 1992, p. 4).

Analysing comparatively the data of group B, which received only oral tips and obtained a learning gain of $35.4 \%$ and group $\mathrm{C}$ which received only written tips and obtained a learning gain of $25.8 \%$, we observe that the oral tips seemed more efficient for inferencing the unknown vocabulary in a foreign language than the written tips. We believe that it is due to the interaction between student-student and student-researcher, in the introductory class offered to group B, in which the researcher elicited the target words from the students. Besides, in the introductory class, the researcher wrote the target words on the board, and the students repeated them, in a chorus, which, according to Connectionism Approach, may have generated reinforcement in the neural synapses responsible for learning, giving salience and emphasis to the words to be learned.

By analyzing each modality separately, we noticed that the oral modality shows better results than the written one. However, it is the combination of both modalities that provides the best scenario for lexical inferencing. It proves, as postulated in The Cognitive Theory of the Multimedia Learning, the positive effect of double-coding since it gives salience to information, which makes learning easier (MAYER 2001, p. 46)

\section{Conclusion}

The present study investigated the use of oral and written tips in the process of lexical inferencing in a hypermedia environment.

We observed that the tips proposed have a significant impact on inferencing, not only in the hypermedia reading environment (webcomics) but also in the multimodal environment (comic books). It is because the tips provide more resources to the student to explore the cues left by the author, and also his or her linguist and world knowledge.

The integrated use of oral + written tips, offered to group A, provided more access to the input. The higher the exposure to the input, according to the Connectionism Approach, the stronger the construction of neural connections, thus favoring learning.

We also verified that the oral tips in an explicit teaching approach, in the short term, produced a better result than the written tips in an implicit 
teaching approach. We believe that this result is due to the students' involvement in the introductory class because, as advocated by the Connectionism Approach, external factors to cognition as motivation, interest, attention, and emotion contribute to the learning process. Despite this result, it is essential to highlight that both tip modalities had a positive impact on lexical inferencing.

In addition to the teaching-learning contributions directly related to our research questions, the webcomics compose a rich teaching material that contributes, among other things, to incentivize reading and Foreign Language learning, in particular, the vocabulary. Thus, the insertion of new technologies such as hypermedia, in the classes, seems to be the way to promote school practices that motivate and involve students to engage in their learning process.

However, it is important to highlight that the development of hypermedia learning environments and the use of them in class is not something simple. They demand teacher valorization, training, and the support of a professional in the area of computer technology.

Considering some limitations of this research, we intended to provide the students with a hypermedia environment with multimodal links, that is, tips given in different media, including sound and movement. However, it was not possible due to the complexity in implementing such an environment. For this reason, we decided to use the Adobe Reader, a software with more limited and straightforward resources, which allowed the researcher herself to transport the comics to the screen and create the links with the tips.

In future studies, we intend to offer oral tips on links as well as improve the tips by providing more information to help students consider other lexical inferencing strategies, such as word class and word formation.

\section{References}

AZEVEDO, Bruno et. al. Vocabulário em Inglês como língua estrangeira: um breve estado da arte no Brasil. Estudos Anglo Americanos, ARAPUI, Santa Catarina, v. 46, n. 2, p. 62-94, 2017.

BOWER, Gordon. How might emotions affect learning? In: CHRISTIANSON, Sven-Ake. (Org.) The handbook of emotion and 
The use of multimodal tips in lexical inferencing...

memory: research and theory. Nova Jersey: Lawrence Erlbaum Associates, 1992. p. 3-32.

CHEGENI; Nastaran.; TABATABAEI, Omid. Lexical Inferencing: The Relationship between Number and Density of Lexical Items and L2 Learners' Reading Comprehension Achievement. Journal of Language Teaching and Research, Finland, v. 5, n. 2, p. 306-312, 2014.

DALE, E. Vocabulary measurement: techniques and major findings. Elementary English, 42, p. 895-901, 1965.

HOSTETLER, Christina. L. Influences on inferences: The roles of L1 transfer and L2 proficiency on L2 lexical inferencing. 2013. Dissertação (Master in Science), Ball State University, Indiana, 2013.

MAYER, Richard. E. Multimedia learning. Cambridge: Cambridge University Press, 2001.

- Multimedia learning: are we asking the right questions? Educational Psychologist, Routledge, Taylor \& Francis Group, v. 32 n. 1, p. 1-19, 1997.

MOTA, Mailce; ZIMMER, Márcia C. Cognição e aprendizagem de L2: o que nos diz a pesquisa nos paradigmas simbólico e conexionista. Rev. Brasileira de Linguística Aplicada, UFMG, Belo Horizonte, v. 5, n. 2, p. 155-187, 2005.

PROCÓPIO, Renata B. O uso do glossário hipermídia no ensinoaprendizagem implícito de vocabulário nos níveis elementar e intermediário de proficiência em inglês. 2016. 118 f. Tese (Doutorado em Linguística) - Faculdade de Letras, UFJF, Juiz de Fora, 2016.

RAMOS, Falcon Dario Restrepo. Incidental vocabulary learning in second language acquisition: a literature review. Profile, v. 17, n. 1, p. 157-166, 2015.

RICHARDS, Jack C. The role of vocabulary teaching. TESOL Quartely 10(1), 1976.

SADEGHI, Karim; AHMADI, Negar. The effect of gloss type and mode on Iranian EFL learners' reading comprehension. English Language Teaching, Canada, v. 5, n. 12, p. 100-110, 2012. 
SANTOS, Mariana Oliveira dos; GANZAROLLI, Maria Emilia. Histórias em quadrinhos: formando leitores. Transinformação [online], Campinas, v. 23, n. 1, p. 63-75, 2011.

SCARAMUCCI, Matilde V. R. O papel do léxico na compreensão em leitura em língua estrangeira: foco no produto e no processo. 1995. 326f. Tese (Doutorado em Linguística) - Instituto de Estudos da Linguagem, Unicamp, Campinas, 1995.

SOUZA, Patrícia N.; BASTOS, Lúcia K. B. O conhecimento lexical no ensino da leitura em língua estrangeira. The ESPecialist, São Paulo, v. 22, n. 1, p. 75-86, 2001.

ZIMMER, Márcia. A leitura em língua estrangeira e os efeitos da frequência e da consistência do insumo lexical em L2. Linguagem em (Dis)curso, Palhoça: Santa Catarina, v. 10, n. 1, p. 111-131, 2010.

\section{Appendix A}

Caro participante,

\section{Questionário de identificação}

Este questionário tem por objetivo conhecer um pouco sobre você e suas práticas para aprendizagem de língua inglesa. As questões devem ser respondidas em português. Se alguma questão não ficou clara para você, não hesite em nos perguntar sua dúvida.

1- $\quad$ Nome completo:

2- Idade:

3- $\quad$ Nome do responsável:

4- Telefone de contato do responsável:

5- E-mail:

6- Você tem o hábito de ler histórias em quadrinhos (HQ)?

( ) Não.

( ) Sim. Qual?

7- Você já leu alguma HQ eletrônica?

( ) Não.

( ) Sim. Qual?

8- Você já leu a história em quadrinhos da Turma da Mônica?

( ) Não.

( ) Sim. 
The use of multimodal tips in lexical inferencing...

9- Você estuda inglês em algum curso livre?

( ) Não.

( ) Sim. Há quanto tempo?

10- Qual o seu nível de conhecimento da língua inglesa?

( ) básico. ( ) intermediário. ( ) avançado.

11- Você geralmente estuda o vocabulário novo em língua inglesa?

( ) Não.

( ) Sim. Que estratégias você utiliza?

a- ( ) decora listas de palavras e sua tradução.

b- ( ) associa a palavra nova a algum objeto, situação, som ou outras palavras.

c- ( ) outras. Especificar:

12- Você usa o computador para estudar vocabulário em língua inglesa?

( ) Não.

( ) Sim. Indique os recursos (CD-ROM, DVD, CD etc.) ou sites utilizados para o estudo:

\section{Appendix B}

Caro participante,

Questionário de avaliação

Leia com atenção as perguntas abaixo e responda com sinceridade. Desde já, agradecemos a sua participação.

1. Você teve dificuldade em navegar no ambiente?

a) ( ) $\operatorname{sim}$

b) ( ) não

Justifique:

2. Como foi a sua experiência com a atividade de leitura mediante o uso dos tablets?

a) ( ) a atividade contribuiu para o aprendizado de palavras desconhecidas.

b) ( ) a atividade não contribuiu para o aprendizado de palavras desconhecidas.

Justifique:

3. Você acha que a leitura de HQ (história em quadrinho) eletrônicas é mais eficiente para o aprendizado do que as HQ no papel?

a) ( ) $\operatorname{sim}$

b) ( ) não

Justifique: 
4. Você acha que as palavras com dicas em links foram suficientes para a compreensão das histórias?
a) ( ) $\operatorname{sim}$
b) ( ) não

Justifique:

5. Você deixou de responder alguma dica em link por não ter entendido a dica da palavra-alvo?
a) ( ) $\operatorname{sim}$
b) ( ) não

Justifique:

6. Você considera que as dicas em links nas palavras-alvo:

a) ( ) foram essenciais para a compreensão dessas palavras.

b) ( ) não foram essenciais para a compreensão dessas palavras.

Justifique:

7. Você acessou todas as dicas em links disponíveis?
a) ( ) $\operatorname{sim}$
b) ( ) não

Justifique:

8. Quando a palavra-alvo aparecia de novo na história, você acessou as dicas em links novamente?
a) ( ) $\operatorname{sim}$
b) ( ) não

Justifique:

9. $\mathrm{O}$ uso de inglês e português juntos nas dicas em links facilitou a compreensão das palavras-alvo?
a) ( ) $\operatorname{sim}$
b) ( ) não

Justifique:

10. Se a dica fosse somente em português, sem nenhuma palavra em inglês, você entenderia melhor as dicas em links?
a) $\quad(\quad) \operatorname{sim}$
b) ( ) não

Justifique: 
The use of multimodal tips in lexical inferencing...

11. A escolha de uma HQ da turma da Mônica, com personagens nacionalmente conhecidos, influenciou na compreensão da história?

a) ( ) $\operatorname{sim}$

b) ( ) não

Justifique:

Você gostaria de fazer algum comentário, crítica ou sugestão em relação ao ambiente de leitura que você navegou ou sobre as histórias escolhidas para esse trabalho?

Recebido em: 01/08/2019

Aceito em: 23/03/2020

Título: O uso de dicas multimodais para inferência lexical em língua inglesa 